\title{
PERANCANGAN MODEL KUALITAS PELAYANAN PUSKESMAS DENGAN METODE IMPORTANCE PERFORMANCE ANALYSIS (IPA) DAN QUALITY FUNCTION DEPLOYMENT (QFD)
}

\author{
Fuji Rahayu Wilujeng, Glisina Dwinoor Rembulan* \\ Program Studi Teknik Industri, Fakultas Teknologi dan Desain, Universitas Bunda Mulia \\ Email: fwilujeng@bundamulia.ac.id; rembulanglisina@gmail.com \\ Artikel masuk : 14-09-2019 \\ Artikel direvisi : 13-10-2019 \\ Artikel diterima : 31-10-2019 \\ *Penulis Korespondensi
}

\begin{abstract}
Abstrak - Jumlah Puskesmas di Provinsi DKI Jakarta mengalami peningkatan sejak tahun 2012 sebanyak 288 unit hingga pada tahun 2016 sebanyak 310 unit. Jumlah unit puskesmas yang meningkat tidak serta merta menjadikan pelayanan puskesmas sudah memadai. Penelitian ini bertujuan untuk mengukur faktor-faktor yang berpengaruh terhadap kepuasan konsumen dan untuk memberikan technical respon yang bersumber dari Voice of Customer. Penelitian ini menggunakan metode Importance and Performance Analysis untuk mengetahui faktor-faktor kualitas pelayanan yang berpengaruh terhadap kepuasan konsumen dan metode Quality Function Deployment digunakan untuk memberikan technical respon. Hasil analisis dengan metode Importance and Performance Analysis menunjukkan faktor-faktor yang termasuk prioritas utama adalah pelayanan terkait pemberian diagnosa yang sesuai oleh dokter di puskesmas, pelayanan terkait respon pihak puskesmas terhadap keluhan (complain) dari pasien, dan atribut pelayanan terkait kesesuaian obat yang diberikan oleh dokter di puskesmas. Peningkatan respon terhadap keluhan pasien merupakan prioritas utama yang harus dilakukan oleh pihak puskesmas untuk meningkatkan kepuasan pasien. Respon teknis dengan urutan prioritas terdepan adalah tenaga medis yang harus memberikan jawaban yang jelas mengenai pengobatan yang dijalani pasien, dan dokter di puskesmas harus lebih teliti dalam memberikan obat yang sesuai dengan penyakit pasien.
\end{abstract}

Kata kunci: Importance and Performance Analysis; Kualitas Layanan; Puskesmas; Quality Function Deployment

\begin{abstract}
The number of Puskesmas in DKI Jakarta Province has increased since 2012 by 288 units to 2016 by 310 units. The increasing number of Puskesmas units does not necessarily make the Puskesmas services adequate. This study aims to measure the factors that influence customer satisfaction and to provide technical responses sourced from Voice of Customer. This study uses the Importance and Performance Analysis method to determine the factors of service quality that affect customer satisfaction, and the Quality Function Deployment method is used to provide a technical response. The results of the analysis using the Importance and Performance Analysis method show that the factors which are of the highest priority are services related to providing appropriate diagnoses by doctors at the Puskesmas, services related to the Puskesmas response to complaints from patients, and service attributes related to the suitability of the drugs provided by doctor at the Puskesmas. Improving responses to patient complaints is a top priority that must be done by the health center to increase patient satisfaction. The technical response in the foremost priority is that medical personnel must provide clear answers about the treatment the patient is undergoing, and doctors at the Puskesmas must be more careful in giving medicines that are appropriate to the patient's illness.
\end{abstract}

Keywords: Importance and Performance Analysis; Puskesmas; Quality Function Deployment; Service Quality 


\section{PENDAHULUAN}

Provinsi DKI Jakarta merupakan provinsi dengan penduduk terpadat dengan angka kesakitan yang masih tinggi di Indonesia. Hal ini harus menjadi perhatian bagi pemerintah daerah Provinsi DKI Jakarta untuk terus mengembangkan kuantitas dan kualitas pelayanan kesehatan yang mencukupi dan memadai bagi penduduk DKI Jakarta. Puskesmas adalah salah satu fasilitas pelayanan kesehatan yang sering digunakan oleh masyarakat. Hal ini dikarenakan biaya pengobatan di puskesmas lebih terjangkau daripada biaya perawatan di rumah sakit atau klinik.

Puskesmas adalah fasilitas pelayanan kesehatan dasar yang disediakan pemerintah dengan menyelenggarakan upaya kesehatan pemeliharaan, peningkatan kesehatan (promotif), pencegahan penyakit (preventif), penyembuhan penyakit (kuratif), dan pemulihan kesehatan (rehabilitatif) (Kementerian Kesehatan Indonesia, 2014). Jumlah Puskesmas di Provinsi DKI Jakarta mengalami peningkatan sejak tahun 2012 sebanyak 288 unit hingga pada tahun 2016 sebanyak 310 unit. Jumlah unit puskesmas yang meningkat tidak serta merta menjadikan pelayanan puskesmas sudah memadai. Di Jakarta Selatan terdapat 25 unit rusak ringan, 15 unit rusak sedang, dan 7 unit rusak berat; Jakarta Timur terdapat 26 unit rusak ringan, 16 unit rusak sedang, 11 unit rusak berat; Jakarta Pusat terdapat 7 unit rusak ringan, 5 unit rusak sedang, dan 1 unit rusak berat; Jakarta Barat terdapat 11 unit rusak ringan; sedangkan di Jakarta Utara terdapat 49 unit puskesmas yang tercatat semuanya dalam kondisi baik.

Kondisi bangunan, ketersediaan fasilitas pendukung, dan akses bantuan seperti ambulans yang memadai menjadi faktor yang menjadikan puskesmas di Jakarta Utara memiliki pelayanan yang berkualitas. Seluruh jalan menuju puskesmas di Jakarta Utara telah dilapisi aspal/beton, air yang bersumber dari PAM, dan listrik yang bersumber dari PLN turut mendukung majunya kualitas pelayanan puskesmas di Jakarta Utara (Kementerian Kesehatan Republik Indonesia, 2017).

Salah satu faktor untuk meningkatkan kepuasan dan kesetiaan pelanggan adalah mutu pelayanan (Dewi, Putri, \& Winarko, 2018). Dalam dunia jasa, mutu pelayanan berpengaruh secara signifikan terhadap kepuasan (Masniari, 2013). Selain itu, kemampuan sosial verbal berpengaruh positif dan paling dimensional antara interaksi perawat-pasien (Mariano et al., 2018)

Salah satu indikator pengukuran kepuasan pelayanan yang biasa digunakan adalah dimensi service quality (servqual) (Putri \& Ikawangi, 2019; Yasril, Dachriyanus, \& Harmawati, 2019; Yuliati,
Magdalena, \& Pratiwi, 2016). Hasil pengukuran kinerja dengan servqual kemudian dianalisis dengan menggunakan Quality Function Deployment (QFD) untuk meningkatkan kualitas pelayanan (Harijono \& Soepangkat, 2011; Joegijantoro, 2012; Magdalena, Arto, \& Ginting, 2013).

Berdasarkan faktor yang berpengaruh terhadap kualitas pelayanan puskesmas di Jakarta Utara terhadap kepuasan pasien dengan metode Importance and Performance Analysis (IPA) dan Quality Function Deployment (QFD). Dimensi dari kualitas pelayanan puskesmas yang akan diteliti terdiri lima dimensi, antara lain tangible (bukti fisik), reliability (kepercayaan), responsiveness (daya tanggap), assurance (jaminan), dan emphaty (empati) (Tjiptono, 2002). Metode IPA digunakan untuk mengetahui faktorfaktor kualitas pelayanan apa saja yang berpengaruh terhadap kepuasan konsumen (Tjoanoto, 2013). Sedangkan metode QFD digunakan untuk memberikan technical respon yang bersumber dari Voice of Customer (VOC) agar dapat meningkatkan kualitas pelayanan puskesmas sehingga bisa meningkatkan kesehatan masyarakat.

\section{METODE PENELITIAN}

Penelitian ini menggunakan kuesioner sebagai data utama yang diolah dengan menggunakan metode Importance and Performance Analysis (IPA) dan Quality Function Deployment (QFD). Secara rinci tahapan metode penelitian ini adalah sebagai berikut:

1. Studi Literatur dan Identifikasi masalah

Permasalahan yang akan dikaji dalam penelitian ini adalah Mengetahui pengaruh faktor-faktor kualitas pelayanan yang ada terhadap kepuasan pasien di beberapa puskesmas di Jakarta Utara. Sedangkan studi literatur dimaksudkan untuk menentukan atribut kualitas layanan dan menyusun kuesioner berdasarkan atribut kualitas layanan berdasarkan yang telah ditentukan.

2. Penyebaran Kuesioner Pengumpulan Data Penyebaran kuesioner dilakukan secara langsung dengan memberikan kepada pasien Puskesmas selama kurang lebih satu bulan. Kuesioner yang digunakan menggunakan skala likert.

3. Evaluasi Model dan Pengolahan Data

Data yang telah dikumpulkan akan dilakukan perhitungan sampel serta uji validitas dan reliabilitas. Apabila ada data yang ditemukan tidak valid maupun tidak reliabel, maka data tersebut tidak dapat digunakan dan akan dilakukan pengumpulan data ulang. Namun apabila data valid dan reliabel akan dilanjutkan 
pada tahap selanjutnya, yaitu pengolahan data menggunakan Metode Importance and Performance Analysis (IPA) dan Quality Function Deployment (QFD) untuk membuat model dan menentukan faktor pelayanan yang berpengaruh terhadap kepuasan pasien.

4. Interpretasi Hasil dan Kesimpulan

Pada bab ini berisi analisa dan penarikan kesimpulan dari penelitian yang sudah dilakukan, serta saran untuk pengembangan pelayanan selanjutnya

\section{HASIL DAN PEMBAHASAN}

Pengumpulan data yang dilakukan dalam menentukan jumlah sampel adalah berdasarkan persyaratan ukuran sampel minimum sebanyak lima responden untuk setiap pertanyaan yang ada dalam kuesioner (Hair, Black, Babin, \& Anderson, 2013). Berdasarkan ketentuan tersebut, maka jumlah sampel yang dibutuhkan dalam penelitian ini adalah 100 responden dengan 20 pertanyaan. Pengambilan kuesioner dilakukan terhadap 100 responden sesuai kriteria dari sampel merupakan para pasien yang tersebar pada tiga puskesmas berbeda di wilayah Jakarta Utara dengan karakteristik sesuai dengan tabel 1 .

Tabel 1. Karakteristik Responden

\begin{tabular}{lllc}
\hline No & Karakteristik & \multicolumn{1}{c}{ Kategori } & Jumlah \\
\hline \multirow{2}{*}{1} & \multirow{2}{*}{ Jenis kelamin } & Laki-Laki & 45 \\
& & Perempuan & 55 \\
\hline \multirow{2}{*}{2} & \multirow{2}{*}{ Usia (tahun) } & $20-24$ & 12 \\
& & $25-29$ & 17 \\
& & $\geq 35-34$ & 34 \\
& & $0-5$ & 37 \\
\multirow{3}{*}{3} & Lama Bekerja & $6-10$ & 32 \\
& (tahun) & $11-15$ & 33 \\
& & $>15$ & 23 \\
\multirow{2}{*}{4} & \multirow{2}{*}{ Riwayat } & Pernah & 12 \\
\cline { 3 - 4 } & Rawat inap & Tidak Pernah & 35 \\
& & & 65
\end{tabular}

Data yang diperoleh dari kuesioner kemudian diuji dengan menggunakan uji validitas dan reliabilitas. Pengujian validitas bertujuan untuk memastikan kelayakan data yang terkumpul agar dapat diteliti lebih lanjut sehingga dapat digunakan untuk mengukur objek yang diteliti (Wilujeng \& Kusumo, 2018). Uji reliabilitas diperlukan untuk memastikan setiap data yang telah dikumpulkan tidak memiliki variansi kesalahan acak. Koefisien yang digunakan dalam uji reliabilitas ini adalah cronbach alpha, yaitu alat ukur yang dapat dikatakan reliabel ketika cronbach alpha > 0,7 (Deng \& Chan, 2017).

Pengolahan data menggunakan software SPSS. Hasil pengolahan data menunjukkan data yang diperoleh valid dan reliabel sehingga dapat dilanjutkan ke langkah selanjutnya (tabel 2). Pengukuran Service Quality dilakukan dengan mengalikan hasil penilaian dengan hasil perhitungan jawaban responden masing-masing atribut dalam kuesioner yang mewakili tingkat harapan dan realita pada pelayanan kesehatan yang dirasakan oleh setiap responden. Berdasarkan ketentuan tersebut diperoleh nilai kepentingan masih lebih besar dari nilai kepuasan (tabel 3). Hasil ini menunjukkan kinerja puskesmas masih dibawah harapan konsumen dengan gap terbesar 0,93 dan gap terkecil sebesar 0,49 . Keseluruhan atribut yang berada di bawah kepentingan responden harus menjadi perhatian yang serius dari pihak manajemen untuk meningkatkan kualitas pelayanan yang diberikan kepada konsumen.

\section{Importance and Performance Analysis (IPA)}

Gap antara tingkat kepentingan dan tingkat harapan mengindikasikan konsumen menginginkan kualitas pelayanan yang lebih dibandingkan dengan kualitas pelayanan yang diterima saat ini. Prioritas perbaikan perlu dilakukan pihak manajemen untuk meningkatkan kepuasan pasien karena tidak semua keinginan pasien bisa dilaksanakan semuanya. Salah metode yang bisa digunakan untuk menentukan prioritas pelayanan perbaikan adalah dengan menggunakan Importance and Performance Analysis (IPA) yang membagi prioritas perbaikan menjadi empat kuadran yaitu prioritas utama, pertahankan prestasi, prioritas rendah, dan berlebihan. Perolehan titik pada diagram kartesius dilakukan dengan menghitung nilai rata-rata dari rata-rata per atribut. Pada hasil pengukuran dimensi atribut kualitas pelayanan di atas dapat ditentukan kepentingan dan kinerja yang ingin diperbaiki. Pihak puskesmas dapat memperhatikan atribut pelayanan yang dianggap penting oleh pasien untuk dapat terpuaskan. Secara terperinci hasil prioritas dimensi yang memerlukan prioritas perbaikan terlihat pada Gambar 1. 
Tabel 2. Uji Validitas dan Reliabilitas

\begin{tabular}{ccccccc}
\hline Atribut & $\begin{array}{c}\text { Corrected } \\
\text { Item Total } \\
\text { Correlation } \\
\text { Tingkat } \\
\text { kepentingan }\end{array}$ & $\begin{array}{c}\text { Corrected } \\
\text { Item Total } \\
\text { Correlation } \\
\text { Tingkat } \\
\text { kepuasan }\end{array}$ & Keterangan & $\begin{array}{c}\boldsymbol{\alpha} \\
\text { Tingkat } \\
\text { kepentingan }\end{array}$ & $\begin{array}{c}\text { a } \\
\text { Tingkat }\end{array}$ & Keterangan \\
kepuasan & & \\
\hline 1 & 0,509 & 0,331 & Valid & 0,895 & 0,869 & Reliabel \\
2 & 0,349 & 0,527 & Valid & 0,899 & 0,861 & Reliabel \\
3 & 0,559 & 0,519 & Valid & 0,893 & 0,862 & Reliabel \\
4 & 0,530 & 0,404 & Valid & 0,895 & 0,866 & Reliabel \\
5 & 0,597 & 0,629 & Valid & 0,892 & 0,858 & Reliabel \\
6 & 0,320 & 0,486 & Valid & 0,899 & 0,863 & Reliabel \\
7 & 0,430 & 0,496 & Valid & 0,897 & 0,863 & Reliabel \\
8 & 0,748 & 0,529 & Valid & 0,887 & 0,861 & Reliabel \\
9 & 0,682 & 0,440 & Valid & 0,889 & 0,865 & Reliabel \\
10 & 0,308 & 0,313 & Valid & 0,899 & 0,869 & Reliabel \\
11 & 0,392 & 0,501 & Valid & 0,897 & 0,863 & Reliabel \\
12 & 0,662 & 0,344 & Valid & 0,890 & 0,868 & Reliabel \\
13 & 0,671 & 0,350 & Valid & 0,890 & 0,867 & Reliabel \\
14 & 0,441 & 0,513 & Valid & 0,896 & 0,862 & Reliabel \\
15 & 0,419 & 0,607 & Valid & 0,897 & 0,858 & Reliabel \\
16 & 0,497 & 0,402 & Valid & 0,895 & 0,866 & Reliabel \\
17 & 0,584 & 0,375 & Valid & 0,892 & 0,867 & Reliabel \\
18 & 0,671 & 0,491 & Valid & 0,890 & 0,863 & Reliabel \\
19 & 0,536 & 0,474 & Valid & 0,894 & 0,863 & Reliabel \\
20 & 0,523 & 0,594 & Valid & 0,894 & 0,858 & Reliabel \\
\hline
\end{tabular}

Tabel 3. Nilai Gap Score

\begin{tabular}{cccc}
\hline Atribut & Nilai Kepentingan & Nilai Kepuasan & Gap Score \\
\hline 1 & 4,24 & 3,71 & 0,53 \\
2 & 4,35 & 3,71 & 0,64 \\
3 & 4,39 & 3,74 & 0,65 \\
4 & 4,36 & 3,75 & 0,61 \\
5 & 4,31 & 3,51 & 0,80 \\
6 & 4,49 & 3,56 & 0,93 \\
7 & 4,35 & 3,65 & 0,70 \\
8 & 4,22 & 3,64 & 0,58 \\
9 & 4,25 & 3,64 & 0,61 \\
10 & 4,32 & 3,68 & 0,64 \\
11 & 4,27 & 3,52 & 0,75 \\
12 & 4,3 & 3,69 & 0,61 \\
13 & 4,35 & 3,5 & 0,85 \\
14 & 4,29 & 3,63 & 0,66 \\
15 & 4,41 & 3,73 & 0,68 \\
16 & 4,29 & 3,79 & 0,50 \\
17 & 4,47 & 3,69 & 0,78 \\
18 & 4,36 & 3,68 & 0,68 \\
19 & 4,27 & 3,78 & 0,49 \\
20 & 4,28 & 3,53 & 0,75 \\
\hline
\end{tabular}




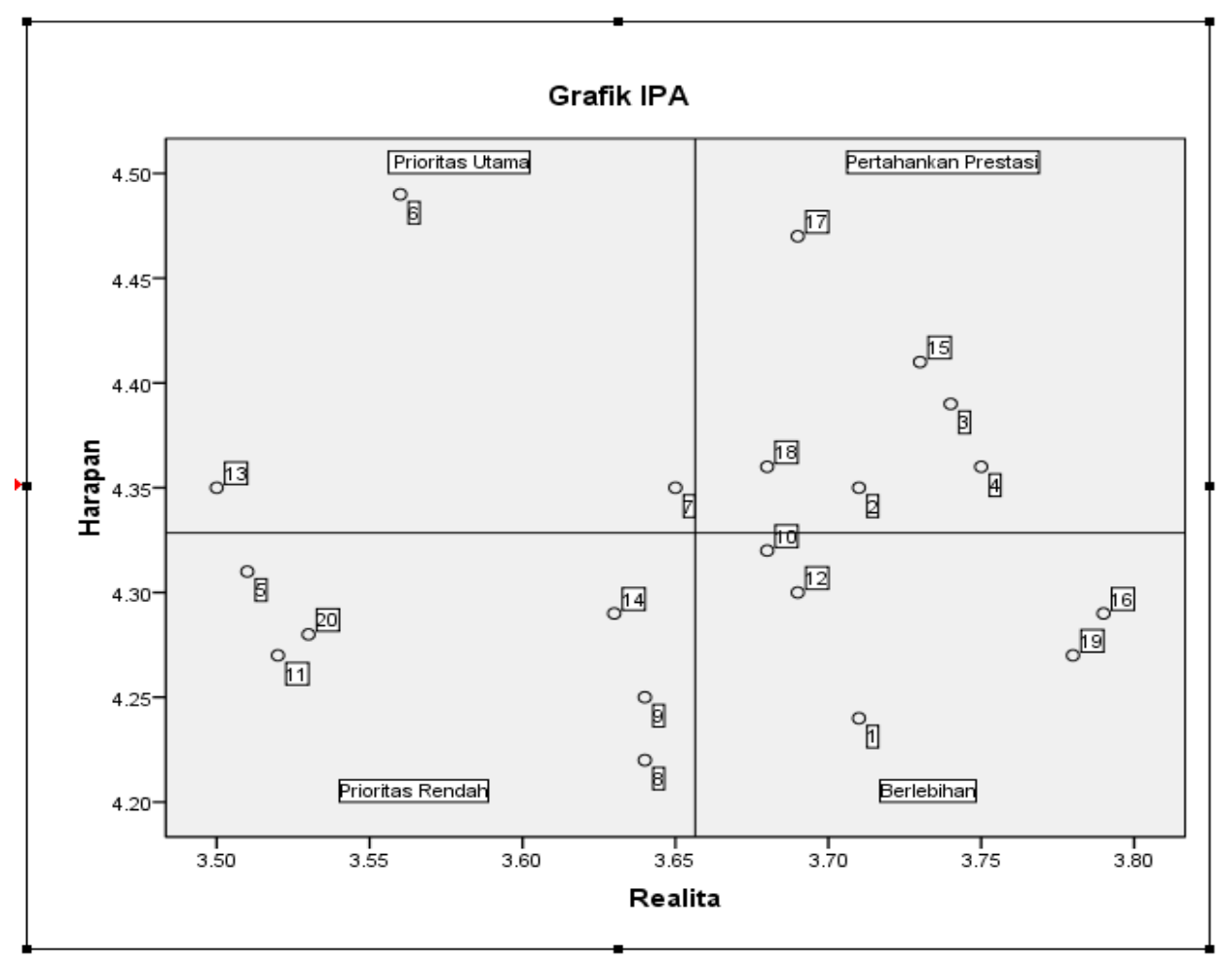

Gambar 1. Diagram Kartesius IPA

Unsur-unsur pelaksanaan atribut pelayanan yang mempengaruhi kepuasan konsumen. Adapun penjelasan dari diagram IPA tersebut adalah sebagai berikut:

1. Kuadran I (Prioritas Utama)

Faktor-faktor yang termasuk ke dalam kuadran pertama adalah atribut pelayanan kesehatan yang memiliki gap score tertinggi, di antaranya: pemberian diagnosa yang sesuai oleh dokter di puskesmas (atribut 6), respon pihak puskesmas terhadap keluhan (complain) dari pasien (atribut 13\}, kesesuaian obat yang diberikan oleh dokter di puskesmas (atribut 7).

2. Kuadran II (Pertahankan Prestasi)

Faktor-faktor yang termasuk ke dalam kuadran kedua yang termasuk ke dalam sepuluh gap score tertinggi di antaranya, yaitu: kesopanan para pegawai di puskesmas dalam melayani pasien (atribut 17), atribut nomor 15 terkait pemenuhan keinginan pasien terhadap pihak puskesmas seperti meminta surat sakit atau resep obat, dan kepercayaan pasien terhadap tenaga medis yang telah menangani pengobatannya secara tepat (atribut 18).

3. Kuadran III (Prioritas Rendah)

Faktor-faktor yang termasuk ke dalam kuadran ketiga yang termasuk ke dalam sepuluh gap score tertinggi di antaranya, yaitu: atribut pelayanan nomor 5 terkait penanganan yang dilakukan oleh tenaga medis di puskesmas untuk pasien, atribut pelayanan nomor 11 terkait kemampuan tenaga medis dalam menjawab pertanyaan pasien, atribut pelayanan nomor 20 terkait dengan kepedulian tenaga medis terhadap kesembuhan pasien, dan kesiagaan tenaga medis dalam menangani penyakit pasien (atribut 14).

4. Kuadran IV (Berlebihan)

Faktor-faktor yang termasuk ke dalam kuadran keempat tidak ada yang termasuk ke dalam sepuluh gap score tertinggi. Oleh sebab itu, dianggap berlebihan jika diupayakan untuk meningkatkan kualitas layanan guna meningkatkan kepuasan pasien. Faktor-faktor yang termasuk ke dalam kuadran ini di antaranya, yaitu: kerahasiaan informasi pengobatan pasien terhadap pihak luar (atribut 10), atribut pelayanan nomor 12 terkait kesesuaian pelayanan bagi pasien BPJS dan non BPJS yang diberikan kepada pihak puskesmas, dan fasilitas media yang memadai di puskesmas (atribut 1).

\section{House of Quality}

House of quality menggambarkan hubungan antara atribut pelayanan pada kuadran I (prioritas utama) yang merefleksikan suara pelanggan (voice of customer) dengan respon yang harus diberikan oleh pihak puskesmas 


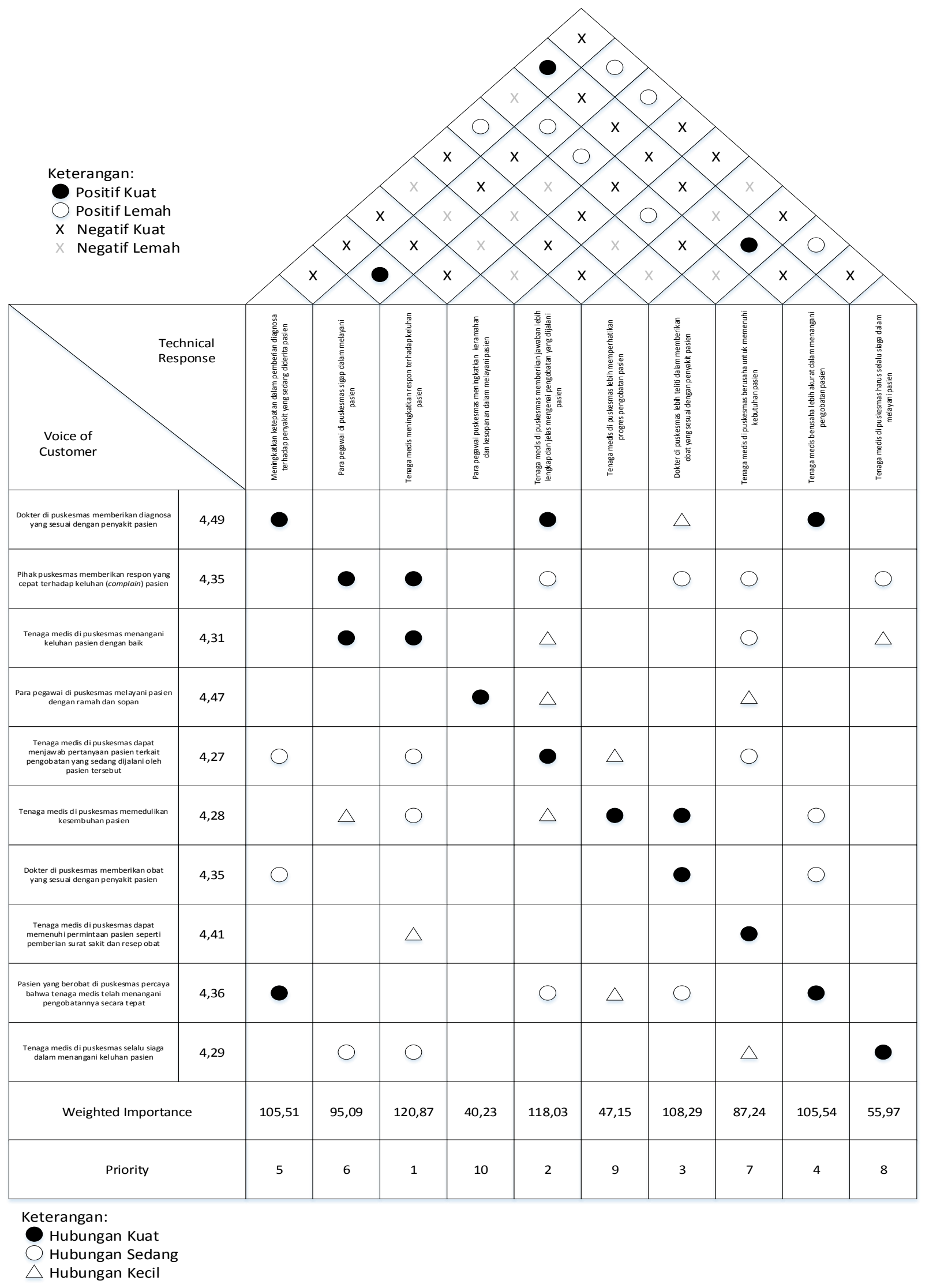

Gambar 2. House of Quality Pelayanan Puskesmas 
(technical response) untuk meningkatkan kepuasan pasien. Meningkatkan respon terhadap keluhan pasien merupakan prioritas utama yang harus dilakukan oleh pihak puskesmas untuk meningkatkan kepuasan pasien. Selain itu, faktor tenaga medis yang harus memberikan jawaban yang lebih lengkap dan jelas mengenai pengobatan yang dijalani pasien, dan dokter di puskesmas harus lebih teliti dalam memberikan obat yang sesuai dengan penyakit pasien juga merupakan respon teknis dengan urutan prioritas terdepan yang harus dilakukan untuk meningkatkan kepuasan pasien. Ketiga respon teknis ini adalah respon yang banyak berhubungan dengan atribut-atribut pelayanan yang lain.

\section{KESIMPULAN}

Hasil analisis dengan metode IPA menunjukkan faktor-faktor yang termasuk ke dalam kuadran pertama (prioritas utama) adalah atribut pelayanan kesehatan yang memiliki gap score tertinggi, yaitu atribut pelayanan terkait pemberian diagnosa yang sesuai oleh dokter di puskesmas, atribut pelayanan terkait respon pihak puskesmas terhadap keluhan (complain) dari pasien, dan atribut pelayanan terkait kesesuaian obat yang diberikan oleh dokter di puskesmas. Peningkatan respon terhadap keluhan pasien merupakan prioritas utama yang harus dilakukan oleh pihak puskesmas untuk meningkatkan kepuasan pasien berdasarkan analisa dengan QFD. Selain itu, faktor tenaga medis yang harus memberikan jawaban yang lebih lengkap dan jelas mengenai pengobatan yang dijalani pasien, dan dokter di puskesmas harus lebih teliti dalam memberikan obat yang sesuai dengan penyakit pasien juga merupakan respon teknis dengan urutan prioritas terdepan yang harus dilakukan untuk meningkatkan kepuasan pasien. Untuk penelitian selanjutnya dapat menambahkan metode pengukuran kualitas lain seperti KANO dan Fuzzy serta meneliti dengan objek yang berbeda.

\section{DAFTAR PUSTAKA}

Deng, L., \& Chan, W. (2017). Testing the difference between reliability coefficients alpha and omega. Educational and Psychological Measurement, 77(2), 185203.

Dewi, S. K., Putri, A. R. C., \& Winarko, B. A. D. (2018). Peningkatan Kualitas Jasa Fasilitas Kesehatan dengan Integrasi Metode IPA dan KANO. Jurnal Sistem Dan Manajemen Industri, 2(2), 67-76.

Hair, J. F., Black, W. C., Babin, B. J., \& Anderson, R. E. (2013). Multivariate data analysis:
Pearson new international edition. Pearson Higher Ed.

Harijono, H., \& Soepangkat, B. O. P. (2011). Upaya peningkatan kualitas layanan farmasi Rsk. St Vincentius A Paulo Surabaya dengan menggunakan metode servqual dan QFD. In Prosiding Seminar Nasional Manajemen Teknologi XIV.

Joegijantoro, R. (2012). Penerapan Quality Function Deployment (QFD) Untuk Mengembangkan Kualitas Pelayanan Rawat Jalan Berorientasi Pelanggan Di Rumah Sakit Paru-Paru. Jurnal IImiah Kesehatan Media Husada, 1(1), 65-75.

Kementerian Kesehatan Indonesia. (2014). Peraturan Menteri Kesehatan Republik Indonesia No 30 Tahun 2014 tentang Standar Pelayanan Kefarmasian di Pukesmas. Jakarta: Kemenkes Republik Indonesia.

Kementerian Kesehatan Republik Indonesia. (2017). Data Dasar Puskesmas. Jakarta: Departemen Kesehatan RI.

Magdalena, M., Arto, S., \& Ginting, R. (2013). Peningkatan kualitas pelayanan dengan menggunakan metode quality function deployment (QFD) di rumah sakit xyz. Jurnal Teknik Industri USU, 3(2), 31-37.

Mariano, M. C. O., et, al. (2018). Social media use profile, social skills, and nurse-patient interaction among Registered Nurses in tertiary hospitals: A structural equation model analysis. International Journal of Nursing Studies, 80, 76-82.

Masniari, R. (2013). Penerapan Metode Structural Equation Modeling (Sem) dalam Menentukan Pengaruh Kepuasan, Kepercayaan dan Mutu terhadap Kesetiaan Pasien Rawat Jalan dalam Memanfaatkan Pelayanan Rumah Sakit di RSUD Dr. Pirngadi Medan Tahun 2012. Kebijakan, Promosi Kesehatan Dan Biostatiskik, 2(1), $1-10$.

Putri, F., \& Ikawangi, L. O. N. (2019). Analisis kepuasan pasien BPJS rawat jalan dengan metode Servqual, CSI, dan IPA di klinik dr. M. Suherman. Jurnal Kesehatan, 5(2), 106115.

Tjiptono, F. (2002). Strategi Pemasaran, edisi kedua. Yogyakarta: ANDI.

Tjoanoto, M. T. (2013). Pengaruh Service Quality Terhadap Customer Satisfaction Di Restoran Jade Imperial. Jurnal Strategi Pemasaran, 1(1), 1-9.

Wilujeng, F. R., \& Kusumo, R. (2018). Analisis Kepuasan Tenaga Kerja Outsourcing terhadap Pelayanan Perusahaan dengan 
Metode Importance-Performance Analysis (IPA). JIEMS (Journal of Industrial Engineering and Management Systems), 11(2), 64-69.

Yasril, T., Dachriyanus, D., \& Harmawati, H. (2019). Hubungan Kualitas Pelayanan Dimensi Servqual dengan Loyalitas Pasien di Poliklinik RSUD Arosuka Tahun 2018. Jurnal Ilmiah Universitas Batanghari Jambi, 19(3), 694-705.

Yuliati, Y., Magdalena, E., \& Pratiwi, D. (2016). Analisis Kepuasan Pasien Farmasi Rawat Jalan Menggunakan Metode Servqual (Studi Kasus Di Rumah Sakit Swasta X Jakarta). Indonesian Journal of Nursing Health Science, 1(1), 1-6. 